\title{
Antiplasmodial Effect of Ethanol Extract of Morinda lucida and Mucuna pruriens Leaves on NK65 Chloroquine Resistant Strain of Plasmodium berghei in Mice
}

Idih $\mathrm{FM}^{1}{ }^{1} 2^{*}$, Ighorodje-Monago $\mathrm{CC}^{1}$ and Ezim OE ${ }^{1}$

${ }^{1}$ University of Portharcourt, Choba, Port Harcourt, Rivers State, Nigeria

${ }^{2}$ Salem University Lokoja, Kogi State, Nigeria

*Corresponding author: Idih FM, University of Portharcourt, Choba, Port Harcourt, Rivers State, Nigeria, Tel: +2348143308906; E-mail: idihfavour@gmail.com

Received date: February 24, 2017; Accepted date: March 10, 2017; Published date: March 17, 2017

Copyright: (C) 2017 Idih FM, et al. This is an open-access article distributed under the terms of the Creative Commons Attribution License, which permits unrestricted use, distribution, and reproduction in any medium, provided the original author and source are credited.

\begin{abstract}
The study evaluated the Antiplasmodial effect of ethanol extract of Morinda lucida (M.L) and Mucuna pruriens (M.P) leaves administered in combination on NK65 chloroquine resistant strain of Plasmodium berghei in mice. Chloroquine (CQ) and artemisinin combination therapy (ACT) were used as standard drugs while the drug vehicle (water) was used as the negative control. The experimental animals divided into 5 groups; group 1=Negative control (water), group 2=Chloroquine $(10 \mathrm{mg} / \mathrm{kg})$, group 3=ACT-Artemeter/Lumefantrine $(20 \mathrm{mg} / 120 \mathrm{mg} / \mathrm{kg})$, group $4=\mathrm{M} . \mathrm{L}$ +M.P $(250 \mathrm{mg} / \mathrm{kg})$, group $5=M . L+M . P(500 \mathrm{mg} / \mathrm{kg})$. There was no decrease in percentage parasitemia of chloroquine treated group, however, there was a continuous significant decrease $(p<0.05)$ in the group treated with ACT. Administration of M.L and M.P in sequence was found to be more effective at the dose of $500 \mathrm{mg} / \mathrm{kg}$ where it continuously and significantly decreased $(p<0.05)$ the percentage parasitemia to $<1 \%$. The administration of the combined extracts of $M$. lucida and $M$. pruriens relatively maintained the Packed Cell Volume (PCV) and the body weight of the mice while reducing the level of parasitemia in them.
\end{abstract}

Keywords: Antiplasmodial; Resistance; Parasitemia; Morinda lucida; Mucuna pruriens

\section{Introduction}

Malaria is a life-threatening disease common to most tropical and subtropical regions, according to World Health Organisation (WHO) an estimated 3.3 billion people in 97 countries and territories are at risk of being infected with malaria, and 1.2 billion are at high risk $(>1$ in 1000 chance of getting malaria in a year). The burden is very heavy in the WHO African Region, where an estimated $90 \%$ of all malaria deaths occur with children aged less than 5 years, accounting for $78 \%$ of all the deaths [1].

Multi-drug resistance has being the major key leading to set back in the combat against malaria, some drugs have being developed over time to counter this phenomenon, but unfortunately some of these drugs are either not readily available or cannot be afforded by those in under-developed regions who forms the majority of the population being affected by the disease.

Chloroquine has being one of the earliest, cheapest and most common antimalarial drug developed over the years [2], but its efficacy has be down trodden by the mechanism of resistance developed by this malaria parasites. Research into exploring the efficiency and feasibility of some common plants to alleviate the resistivity of malaria parasite to chloroquine will be a major breakthrough in the move to reduce or eliminate malaria cases. This can be achieved if a totally separate therapeutical agent other than chloroquine such artemisinin identified by a Chinese scientist Tu Youyou in 1997 from Artemisia annua, or a therapeutic agent that can counter the resistivity developed by the parasite against chloroquine can be found [3].
Medicinal plants have always being discovered and utilized throughout human history. Plants have the capability to synthesize wide range and varieties of phytochemical compounds that have the ability to exert important biological functions. Some of these phytochemicals have been widely researched and confirmed to possess medicinal properties.

Morinda lucida is a medium size tropical tree about $15 \mathrm{~m}$ tall having a scaly grey bark with short crooked branches and shining foliage, its leaves are used in some part of Nigeria for traditionally treating malaria [4], while some use it alongside with Mucuna pruriens a plant belonging to the family fabaiceae, an annual climbing legume of relative height of about 3-18 m, which is indigenous to tropical regions, especially Africa, India, and the West Indies. M. pruriens which leaves possess the potential to act as a booster for red blood cell (RBC) production [5] is believed to revert the anemia resulting from malaria.

This research is designed to explore the antiplasmodial potential of the combined extracts of $M$. lucida and $M$. pruriens against chloroquine resistant strain of Plasmodium berghei.

\section{Materials and Methods}

\section{Plant collection}

Morinda lucida and Mucuna pruriens leaves were collected from a farmland in Ejule, Ofu Local Government of Kogi State, Nigeria and identified by a Botanist of the Department of Biological Sciences, Kogi State University Anyibga, Kogi State. 
Citation: Idih FM, Ighorodje-Monago CC, Ezim OE (2017) Antiplasmodial Effect of Ethanol Extract of Morinda lucida and Mucuna pruriens Leaves on NK65 Chloroquine Resistant Strain of Plasmodium berghei in Mice. Clin Exp Pharmacol 7: 234. doi: $10.4172 / 2161-1459.1000234$

Page 2 of 4

\section{Experimental animals and malaria parasite}

The mice with average weight of $25 \mathrm{~g}$ were purchased from the animal section of Salem University, Lokoja, Kogi State. The animals were acclamatised in the experimental room for 2 weeks.

Mice infected with chloroquine resistant NK65 Plasmodium berghei $\left(1 \times 10^{7}\right.$ infected red blood cells) were taken from the Institute of Advanced Medical Research and Trainings (IAMRAT), University College Hospital, University of Ibadan, Nigeria.

\section{Preparation and extraction of plant sample}

The leaves of M. lucida and M. pruriens leaves were air dried and ground into powdery form using a Binatone BLG-450 blender. The ground leave samples were extracted with soxhlet extractor, using absolute ethanol as solvent.

The extracts were dried in evaporating dishes after solvent recovery in the soxhlet extractor; the extracts were transferred to an oven for further drying at the temperature of $40^{\circ} \mathrm{C}$. The percentage yield was also calculated by subtracting the weight after extracting from the weight before extraction.

\section{Inoculation of malaria parasite}

The donor mice were anesthetized using chloroform; blood was taken from them by cardiac puncture and immediately transferred into normal saline. The experimental animals were infected by intraperitoneal injection of $0.2 \mathrm{ml}$ of the inoculum $\left(1 \times 10^{7}\right.$ infected erythrocytes); they were then left for 4 days to allow spread and multiplication of the parasite in their blood [6].

\section{Experimental design}

The inoculated mice with average weight of $25 \mathrm{~g}$ were grouped as follows with 3 animals per group:

Group 1 were given only water. $\mathrm{kg})$.

Group 2 (positive control) which were given chloroquine (10 mg/

Group 3 (positive control) were given Artemeter/Lumefantrine (ACT) $20 \mathrm{mg} / 120 \mathrm{mg} / \mathrm{kg}$.

Group 4 were given $250 \mathrm{mg} / \mathrm{kg}$ of combined extracts of M. lucida and $M$. pruriens.

Group 5 were given $500 \mathrm{mg} / \mathrm{kg}$ of combined extracts of M. lucida and M. pruriens.

\section{Treatment of experimental animals}

The experimental animals were treated accordingly for 3 days following the details of their grouping above. The dosing of the animals was done orally with the aid of an intubator.

\section{Weight determination}

The experimental animals were weighed before parasite inoculation, after parasite inoculation, before and after treatment.

\section{Determination of packed cell volume (PCV)}

The packed cell volume determination was done for the experimental animals after inoculation, before and after treatment [7]. This was done to deduce the effect of the parasite on the red blood cells (RBC) and also the effect of the extracts on the RBC. The PCV was done by collecting blood from the tail of the experimental animals into heparinised capillary tubes which were sealed up from one end and then centrifuged at $3000 \mathrm{rpm}$ for $5 \mathrm{~min}$; the PCV was then read using a hematocrit reader.

\section{Determination of percentage parasitemia}

This was done according to the method by Monica [8]. Blood was collected from the tails of the experimental animals on slides and smeared into thin film. The slides were air dried and the stained with Leishman's stain, this was done by adding 8 drops of the stain to the slides and leaving them for $2 \mathrm{~min}$, the stain was then diluted with buffered water $(\mathrm{pH} \mathrm{6.8)}$ ) and allowed to stay for $8 \mathrm{~min}$ after which it was washed off the slides with distilled water. The slides were air dried and viewed using light microscope at X100 magnification with oil immersion.

The parasitemia was determined before, during and after treatment.

The percentage parasitemia was calculated using a formula [6]:

Percentage parasitemia $=\frac{\text { Number of parasitized } R B C}{\text { Total number of } R B C} \times 100$

\section{Results}

\section{Packed cell volume (PCV) of chloroquine resistant strain induced animals}

Table 1 show the effect of ethanol extract of Morinda lucida and Mucuna pruriens leaves on packed cell volume (PCV) of chloroquine resistant strain Plasmodium berghei induced mice. There was a decrease in the PCV of the untreated animals, those treated with only $M$. lucida and those treated with $250 \mathrm{mg} / \mathrm{kg}$ of $M$. lucida and $M$. pruriens, but these decrease were not statistically significant $(\mathrm{p}>0.05)$, likewise there was increase in $\mathrm{PCV}$ in the groups treated with artemisinin combination therapy (ACT), chloroquine (CQ) and 500 $\mathrm{mg} / \mathrm{kg}$ of $M$. lucida and $M$. pruriens, but these were not also statistically significant $(\mathrm{p}>0.05)$.

\begin{tabular}{|l|l|l|}
\hline Groups and Doses & Before Treatment & After Treatment \\
\hline Negative control & $40.00 \pm 2.89$ & $33.33 \pm 2.89$ \\
\hline $\mathrm{CQ}$ & $40.67 \pm 1.16$ & $41.67 \pm 2.89$ \\
\hline $\mathrm{ACT}$ & $41.33 \pm 2.30$ & $41.67 \pm 2.89$ \\
\hline $250 \mathrm{mg} / \mathrm{kg}(\mathrm{ML}+\mathrm{MP})$ & $40.00 \pm 5.00$ & $36.67 \pm 2.89$ \\
\hline $500 \mathrm{mg} / \mathrm{kg}(\mathrm{ML}+\mathrm{MP})$ & $38.33 \pm 2.89$ & $40.00 \pm 2.89$ \\
\hline
\end{tabular}

Table 1: Effect of ethanol extract of Morinda lucida and Mucuna pruriens leaves on packed cell volume (PCV) of chloroquine resistant strain Plasmodium berghei induced mice. Values represents mean \pm S.D of $\mathrm{n}=3$. 
Citation: Idih FM, Ighorodje-Monago CC, Ezim OE (2017) Antiplasmodial Effect of Ethanol Extract of Morinda lucida and Mucuna pruriens Leaves on NK65 Chloroquine Resistant Strain of Plasmodium berghei in Mice. Clin Exp Pharmacol 7: 234. doi: 10.4172/2161-1459.1000234

Page 3 of 4

\section{Body weight of chloroquine resistant strain induced animals treated with Morinda lucida and Mucuna pruriens}

Figure 1 shows the effect of ethanol extract of $M$. lucida and $M$. pruriens leaves on body weight of chloroquine resistant strain $P$. berghei induced mice. There was a decrease in the body weight of the untreated group at day 14 and 21 and these were statistically significant $(p<0.05)$. There were no significant decreases or increase in the body weight of the other groups.

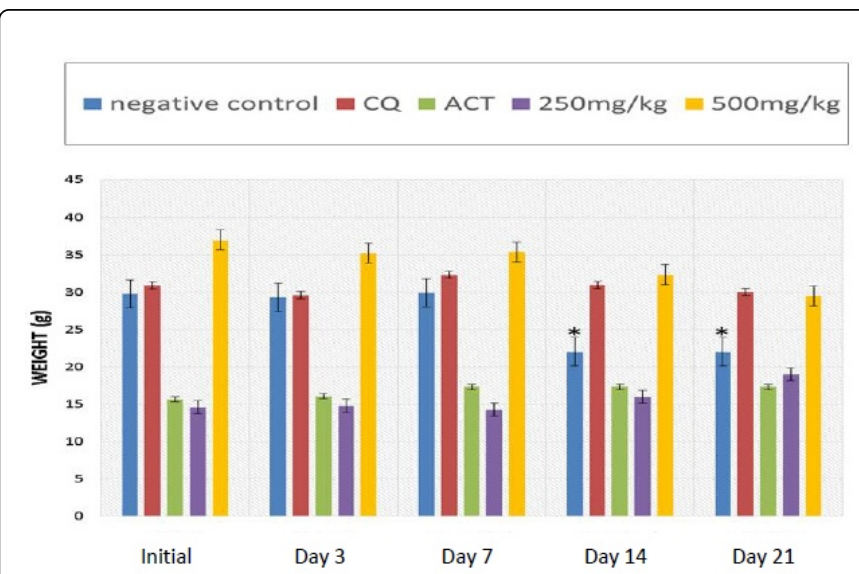

Figure 1: Effect of ethanol extract of Morinda lucida and Mucuna pruriens leaves on body weight of chloroquine resistant strain Plasmodium berghei induced mice. ${ }^{*}$ Represents significant difference at $\mathrm{p}<0.05$ when the body weight at day 3, Day 7, Day 14, Day 21 was compared to the initial body weight.

\section{Percentage parasitemia of resistant strain induced animals treated with Morinda lucida and Mucuna pruriens}

Figure 2 shows the effect of ethanol extract of M. lucida and $M$. pruriens leaves on parasitemia of chloroquine resistant strain $P$. berghei induced mice. There was a significantly continuous increase in the percentage parasitemia of the untreated group. There was an increase in the percentage parasitemia which went up rapidly at day 14 and 21 due to the fact the chloroquine was partially effective and thus did not permit excessive increase during the early days (day 3 and 7) of treatment of the group treated with $\mathrm{CQ}$, but was not statistically significant at $(p>0.05)$. There was a continuous significant decrease in the group treated with ACT. There was a decrease in the percentage parasitemia of the group treated with $250 \mathrm{mg} / \mathrm{kg}$ of $M$. lucida and $M$. pruriens, but was only significant at day 21 . Also there was a decrease in the percentage parasitemia of the group treated with $500 \mathrm{mg} / \mathrm{kg}$ of M. lucida and M. pruriens which was significant day 7, 14 and 21 .

\section{Discussion}

A report in 2015 by World Health Organization (WHO) on World Malaria Day stated that malaria is a preventable and treatable disease. The primary objective of malaria treatment is to completely eliminate the parasite from patients' blood in order to curtail the advancement of uncomplicated malaria to severe cases, chronic infection that leads to malaria-related anemia and possibly death [1].

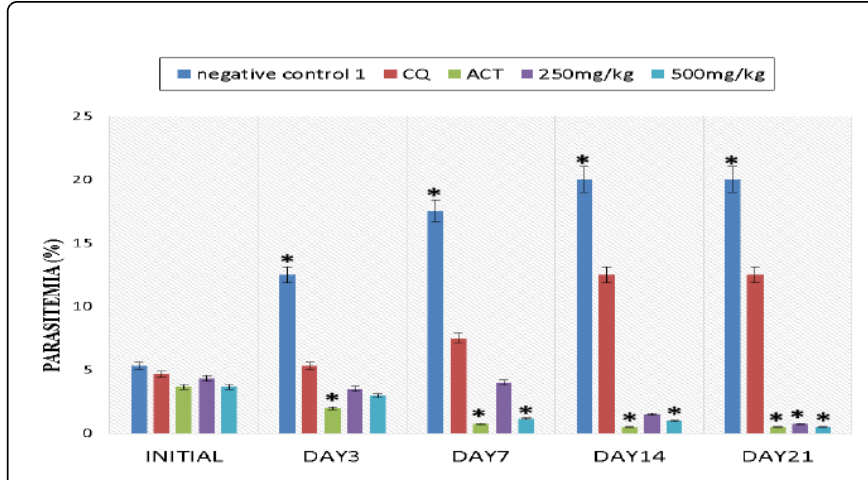

Figure 2: Effect of ethanol extract of Morinda lucida and Mucuna pruriens leaves on parasitemia of chloroquine resistant strain Plasmodium berghei induced mice. ${ }^{*}$ Represents significant difference at $\mathrm{p}<0.05$ when the parasitemia (\%) of the test and control groups at day 3 , day 7 , day 14 and day 21 was compared to the parasitemia (\%) before treatment (initial).

According to a statement by WHO in 2002, an estimate of about eighty percent of the population of some Asian and African countries currently use herbal medicine for primary health care purposes. Among some of the major factors challenging the use of medicinal plants include little or no knowledge on the mechanism of action, dose limit and composition of these medicinal plants.

One of the resultant effects of malaria on the blood of infected host is reduction in the number Red Blood Cells (RBC) leading to an anemic condition; this is due to low production and increased destruction of red blood cells during malaria infection [9]. It was observed in this study as shown in Table 1 that $P$. berghei chloroquine resistant strain infected animals treated with the combined extracts of Morinda lucida and Mucuna pruriens had relative stability in their PCV. This finding agrees with what was reported by Akindele and Busayo on the ability of $M$. pruriens in stabilising PCV [5].

Reduction in body weight is one of the effects of malaria infection as the disease may lead to loss of appetite and disruption of other vital activities. In this study it was observed in the P. berghei chloroquine resistant strain infected animals (Figure 1) that there was a continuous decrease in the body weight of the untreated animals which became statistically significant at $p<0.05$ on day 14 and 21 of the infection. This was not so in the group treated with the extracts as no significant decrease in body weight was observed in them. These observations are in accordance with reports by other researchers [10].

Percentage parasitemia expresses the level of infection in the host blood, in the case of malaria parasites this is said to be the number of infected RBCs against that of normal RBCs. This study revealed as presented in Figure 2 that in $P$. berghei chloroquine resistant strain infected animals, there was a significantly continuous increase in the percentage parasitemia of the untreated group, there was no decrease but rather a continuous increase in percentage parasitemia was observed in the group treated with chloroquine though this was not significant ( $\mathrm{p}>0.05$ ); this may be as a result of the resistance adopted by the parasite against chloroquine [11]. A significantly continuous decrease in percentage parasitemia was observed in the group treated with ACT; this is due to the effectiveness of ACT on chloroquine resistant malaria infection [12]. 
Citation: Idih FM, Ighorodje-Monago CC, Ezim OE (2017) Antiplasmodial Effect of Ethanol Extract of Morinda lucida and Mucuna pruriens Leaves on NK65 Chloroquine Resistant Strain of Plasmodium berghei in Mice. Clin Exp Pharmacol 7: 234. doi: $10.4172 / 2161-1459.1000234$

Page 4 of 4

It was observed that the group treated with $250 \mathrm{mg} / \mathrm{kg}$ of $M$. lucida and $M$. pruriens, had their percentage parasitemia significantly reduced, but a continuous significant decrease in percentage parasitemia was observed in the group treated with $500 \mathrm{mg} / \mathrm{kg}$ of $M$. lucida and $M$. pruriens. This shows that the treatment was more pronounced and effective at $500 \mathrm{mg} / \mathrm{kg}$. These observations coincide with other findings [13] on the antimalarial potency of M. lucida and M. pruriens.

\section{Conclusion}

The combined administrations of Morinda lucida and Mucuna pruriens leaves extracts at suitable doses reduced the parasite load and were able to maintain the PCV at a normal range with a stabilising effect on body weight in both chloroquine resistant and chloroquine sensitive strain $P$. berghei infection.

Since M. lucida and $M$. pruriens are widely distributed across Africa and Asia, where malaria tends to be at its peak, further studies into the feasibility of isolating, identifying and characterising the active compounds responsible for the antiplasmodial activity of these leaves will help in reducing the malaria burden in this region.

\section{References}

1. Farnsworth NR, Akerele O, Bingel AS, Soejarto DD, Guo Z (1985) Medicinal plants in therapy. Bull World Health Organ 63: 965-981.

2. Muheet AS, Tanveer B, Abdul HH, Fahad SHA, Saleh AQ (2013) Antimalarial drugs: Mode of action and status of resistance. Afr J Pharm Pharmacol 7: 148-156.
3. Tu YY (1981) The awarded Chinese invention: antimalarial drug quinhaosu [in Chinese]. Rev World Invent 4: 26.

4. Lawal HO, Etatuvie SO, Fawehinmi AB (2012) Ethnomedicinal and pharmacological properties of Morinda lucida. J Nat Prod 5: 93-99.

5. Akindele AJ, Busayo FI (2011) Effects of the hydroethanolic extract of Mucuna pruriens (L.) DC (Fabaceae) on haematological profile in normal and haloperidol treated rats. Nig Q J Hosp Med 21: 93-98.

6. Mikhail ON, Taoheed AA, Musbau AA (2013) Phytochemical analysis and antimalarial activity of aqueous extract of Lecaniodiscus cupanioides root. J Trop Med pp: 1-4.

7. David LH (2014) Methods of hematology. Sweet Haven Publishing Service.

8. Monica C (2005) Hematological test: blood films. District Laboratory Practice in Tropical Countries 8.

9. Menendez C, Fleming AF, Alonso PL (2000) Malaria-related anaemia. Parasitol Today 16: 469-476.

10. Basir R, Rahiman SF, Hasballah K, Chong W, Talib H, et al. (2012) Plasmodium berghei ANKA infection in ICR mice as a model of cerebral malaria. Iran J Parasitol 7: 62-74.

11. Bray PG, Mungthin M, Riley RG, Ward SA (1998) Access to hematin the basis of chloroquine resistance. Mol Pharmacol 54: 170-179.

12. Badejo JA, Abiodun OO, Akinola O, Happi CT, Sowunmi, et al. (2014) Interaction between rifampicin, amidiaquinine and atemether in mice infected with chloroquine resistant Plasmodium berghei. Malar J 13: 299.

13. Umar MB, Ogbadoyi EO, Ilumi JY, Salawu OA, Tijani AY, et al. (2013) Antiplasmodial efficacy of methanolic root and leaf extracts of Morinda lucida. J Nat Sci Res. 